\title{
The Algorithm of Semi-automatic Thai Spoonerism Words for Tri-syllable
}

\author{
Nutthapat Kaewrattanapat
}

\begin{abstract}
The purposes of this research are to study and develop the algorithm of Thai language spoonerism words by semi-automatic computer programs, that is to say, in part of data input, syllables are already separated and in part of spoonerism, the developed algorithm is utilized, which can establish rules and mechanisms in Thai spoonerism words for Tri-syllables by utilizing analysis in elements of the syllables, namely cluster consonant, vowel, intonation mark and final consonant. From the study, it is found that Tri-syllable Thai spoonerism has 2 cases of spoonerism mechanism. In the first case is a crossing between the first syllable to the third syllable and second case is a crossing between the second syllable to the third syllable. From the study, the rules and mechanisms in Thai spoonerism word were applied to develop as Thai spoonerism word software, utilizing PHP program. the software was brought to conduct a performance test on software execution; it is found that the program performs Tri-syllable Thai spoonerism correctly or $90 \%$ of all words used in the test and found faults on the program at $10 \%$ as the words obtained from spoonerism may not be spelling in conformity with Thai grammar and not possible to predict the real answer is to look through the tri-syllable, then the answer is because the two cases depending on the aim of creating a spoonerism it.
\end{abstract}

Index Terms-Algorithm, Thai spoonerism word, Tri-syllable spoonerism word, computational linguistics.

\section{INTRODUCTION}

Humankind uses language as the tool for communication in different forms corresponding to events or experience happened in daily life for negotiation, talking in several matters by verbal language or non-verbal language in order to express meaning for understanding correspondingly; therefore, language is an important factor for expressing meaning "what speaker wants to say" to listener for understanding correspondingly; moreover, nowadays, the evolution in language is changing according to social and cultural age, greatly affecting in language usage either in any form [1], [2].

Culture of Language could, therefore, be regarded as one

Manuscript received July 15, 2015; revised November 20, 2015. This work was supported by Suan Sunandha Rajabhat University: SSRU, Bangkok, Thailand (http://www.ssru.ac.th/) to provide funding support to attend the dissemination of research on this and thank family, friends, colleagues and students in the field of Information Management for cooperation in research, all of you. Finally, thanks to the Thai language which is our national language with its complicated grammars and structures that challenge the natural language processing.

Nutthapat Kaewrattanapat is with Information Management Program, Suan Sunandha Rajabhat University, Bangkok, Thailand 10300 (e-mail: nutthapat.k@ssru.ac.th). kind of art affecting in communication [3]. The researcher perceived the beauty of pun in language usage; therefore, a design was conducted to demonstrate spoonerism by utilizing linguistic rules to support in spoonerism for creating knowledge, including functions and rules in spoonerism to obtain concrete and certain method in spoonerism as spoonerism is the art of word play having twisting between transposition of sound or syllables; this indicates that Thai language is always shifting and changing constantly, all of which are the trait of Thai people as the purpose of spoonerism is to use for playing for enjoyment and compete linguistic intelligence being regarded as a demonstration of linguistic ability [4], [5].

The researcher envisioned the importance in Thai spoonerism play; thus, the study of Thai spoonerism was conducted by analyzing elements of syllables in each syllable, namely consonant, vowel, intonation mark and final consonant in order to find probability of spoonerism and establish rule and mechanism in Thai spoonerism for Tri-syllable and store the knowledge related to Thai spoonerism in order to have the certain form. For the study of algorithm in spoonerism, the researcher collected the obtained knowledge from the study for conducting a computer-language algorithm structure by utilizing PHP language programing and word processing as the interested persons could bring it to study and develop in several fields further.

\section{OBJECTIVE}

The aim is to study a Thai spoonerism algorithm and establish rules or mechanisms in Semi-automatic Thai spoonerism for Bi-syllable and Tri-syllable.

\section{EXPECTED OUTCOMES}

1) To Obtain More Computational Linguistics Knowledge and be able to bring such obtained knowledge to develop further in order to increase a performance in the program further.

2) To Obtain Forms of Rules and Mechanisms in Thai language spoonerism in order to be guidelines for applying with related subjects to be new guidelines in the study.

3) To Obtain System of the Linguistic Program for Application from several subjects which is collected and analyzed until it generates new knowledge.

4) Can be Used to Analyze the Sentiment Analysis in the future, which are needed in Thai language because of the spoonerism is a factor or effect the opinion of messages. 


\section{LITERATURE REVIEW}

\section{A. Definition of Spoonerism}

The Royal Institute of Thailand (B.E.2546) gave the definition of "spoonerism" as "a reversible word such as "Tok-Tee-It" (“ตก-ที่-อิฐ”, Falling bricks) to be “Tit-Tee-Ok” (“ติด-ที่-อก”, Breast stuck) as spoonerism words.

\section{B. Element of Thai Syllable}

Syllable in Thai language has 3 important elements, including initial consonant + vowel sound+ intonation tone.

Initial consonant sound is such as a consonant which is pronounced before the other consonant; initial consonant can be single initial consonant or initial cluster consonant, for example Pāt and Prāt [6].

TABLE I: EXAMPLE OF THAI SYLLABLE

\begin{tabular}{lll}
\hline \hline \multicolumn{1}{c}{ Thai } & \multicolumn{1}{c}{ English } & \multicolumn{1}{c}{ Syllable } \\
\hline ไร่ & Farm & Rai (Syllable) \\
ชาวไร่ & Farmer & Chāo-Rai (2-Syllables) \\
สหกรณ์ & Cooperative & Sa-ha-kon (3-Syllables) \\
โรงพยาบาล & Hospital & Rōng-pha-yā-bān(4-Syllables) \\
นักศึกษาผู้ให & Adult Students & Nak-seuk-sā-phū-yai(5-Syllables) \\
ญ่ & & \\
สหกรณ์การเ & Agricultural & Sa-ha-kon-kan-ka-sēt \\
กษตร & cooperative & (6-Syllables) \\
\hline \hline
\end{tabular}

Vowel sound is such as a sound pronounced along with consonant swiftly, making initial consonant pronounced clearly; vowel can be short-sound single vowel, long-sound single vowel or diphthong mixed with any one of sound.

Intonation tone is such as high-pitch or low-pitch sound pronounced with vowel [7].

Elements of syllable have 3 important parts, namely initial consonant, vowel, intonation mark (having or not having a letter representing sound). Praya Upakit Silapasarn (B.E.2533) explained the elements of syllable that it is created by compounding letter having 4 forms which could be summarized as follows [8], [9]:

1) Compounding 3 parts of letters, such as syllable generated from compounding of initial consonant + vowel + intonation mark, for example มี $\left(\mathrm{M}_{\overline{1}}=\right.$ Have $)$, นา $(\mathrm{Na}=$ Field $)$ ห้า $(\mathrm{Ha}=$ Five $)$, ไร่ $($ Rai $=$ Farm $)$ etc.

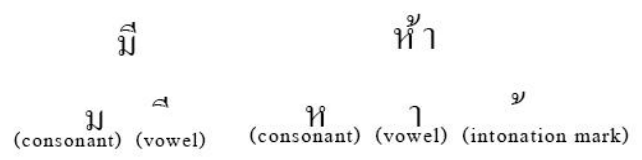

Fig. 1. Compounding 3 parts of letters.

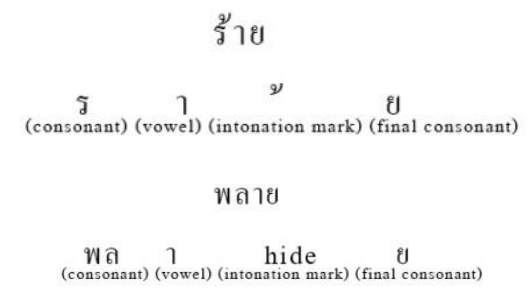

Fig. 2. Compounding 4 general parts of letters.

2) Compounding 4 general parts of letters, such as syllable generated from compounding of initial consonant + vowel + final consonant + intonation mark, for example

พลาย $($ Phla $=$ Elephant $)$ and งาม $($ ngām $=$ Beautiful $)$ etc.

3) Compounding 4 special parts, such as syllable generated from compounding of initial consonant + vowel + intonation mark + mute intonation mark, for example เล่ห์ $(\mathrm{Le}=\mathrm{Trick})$, สีห์ $(\mathrm{S} \overline{1}=\mathrm{Lion})$, เบียร์ $(\mathrm{Beer}=\mathrm{Beer})$ etc.

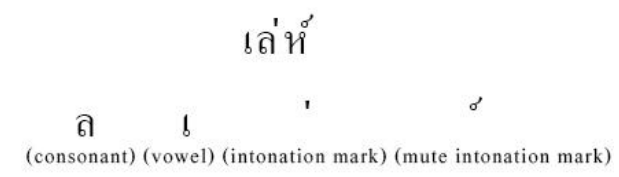

Fig. 3. Compounding 4 special parts.

4) Compounding 5 parts, such as syllable generated from compounding of initial consonant + vowel + final consonant + intonation mark + mute intonation mark, for example ลักษณ์(Lak = Image) ,ขันธ์(Khan = Group) and จันทร์(Jan = Moon) and etc.

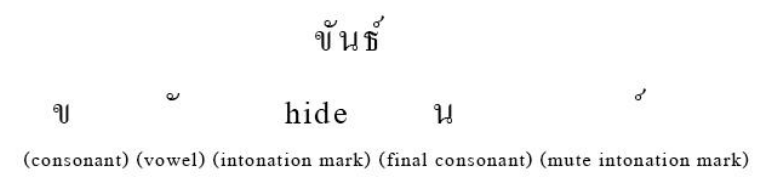

Fig. 4. Compounding 5 parts.

From the Table I, it demonstrates that syllable is the sound pronounced one time, whether having meaning or not; if it is pronounced 1 time, that means 1 syllable; if it is pronounced 2 times, that means 2 syllables according to Thai grammar.

\section{METHOD AND RESUlt}

\section{A. Rules of Bi-syllable Spoonerism}

Probability of answers based on the theory of mathematical probability is Tri-syllable word generating the probability as $(3 !) / 2=3$; (division 2 because it is not a repeat count) therefore, the answer of the spoonerism can't generate results not more than 3 answers.

1) As for spoonerism of Bi-syllables, the first syllable and second syllable must not have the same initial-sound consonant. If there are same initial-sound consonant, the spoonerism can't be conducted as the results will be only word transposition, for exampleñาง-เกิง (Kāng-kēng), โพิง-พิาง(Phøng-phāng), แส่ง-สี(Sangsi) and etc.

2) For spoonerism of Bi-syllable, the vowel form and final consonant must be the same sound, namely for example รา-ชา $(\mathrm{R} \overline{\mathrm{a}}-\mathrm{ch} \overline{\mathrm{a}})$, ชม-รม (Chom-rom)

3) Bi-syllable that when being pronounced as 3 syllables or compound word must use the rules of spoonerism for Tri-syllable, and the data must be enter as reading word only because, if the rules of spoonerism for Bi-syllables is used in encoding, the spoonerism could not be conduct correctly and compound-word sound in the middle of words will be omitted, for example the word เท-ศ-กาล"thēt-sa-kān". If the word "thēt-sa-kān" is 
conducted spoonerism based on Bi-syllables basis, the results will be "than-la-kēt"; however, if "thēt-sa-kān" is conducted spoonerism based on tri-syllable basis by entering data as reading word "Thēt-Sa-Kān", the result will be "Thān-Sa-Kēt".

4) Vowel and final consonant which should be avoided to use in spoonerism as it will be resulted in impoliteness, such as syllable consisted of vowel " 3 " having "ด" as final consonant; syllable consisted of vowel " $æ$ " having “ด” as final consonant; syllable consisted of "au" having "ย"as final consonant; syllable consisted of "i"; syllable consisted of "o"; syllable consisted of "um"; syllable consisted of "ai" ( ไand ใ).

5) Bi-syllable and Tri-syllable spoonerism functions by utilizing linguistic rules, from the study and data research relevant to spoonerism words, we brought above-mentioned rules of Bi-syllables spoonerism converting it into functions by utilizing linguistic theory for supporting in analysis by connecting them with elements of structure in syllable. Therefore, the variables in spoonerism is obtained as Table II.

\section{TABLE II: ASSIGNING VARIABLES}

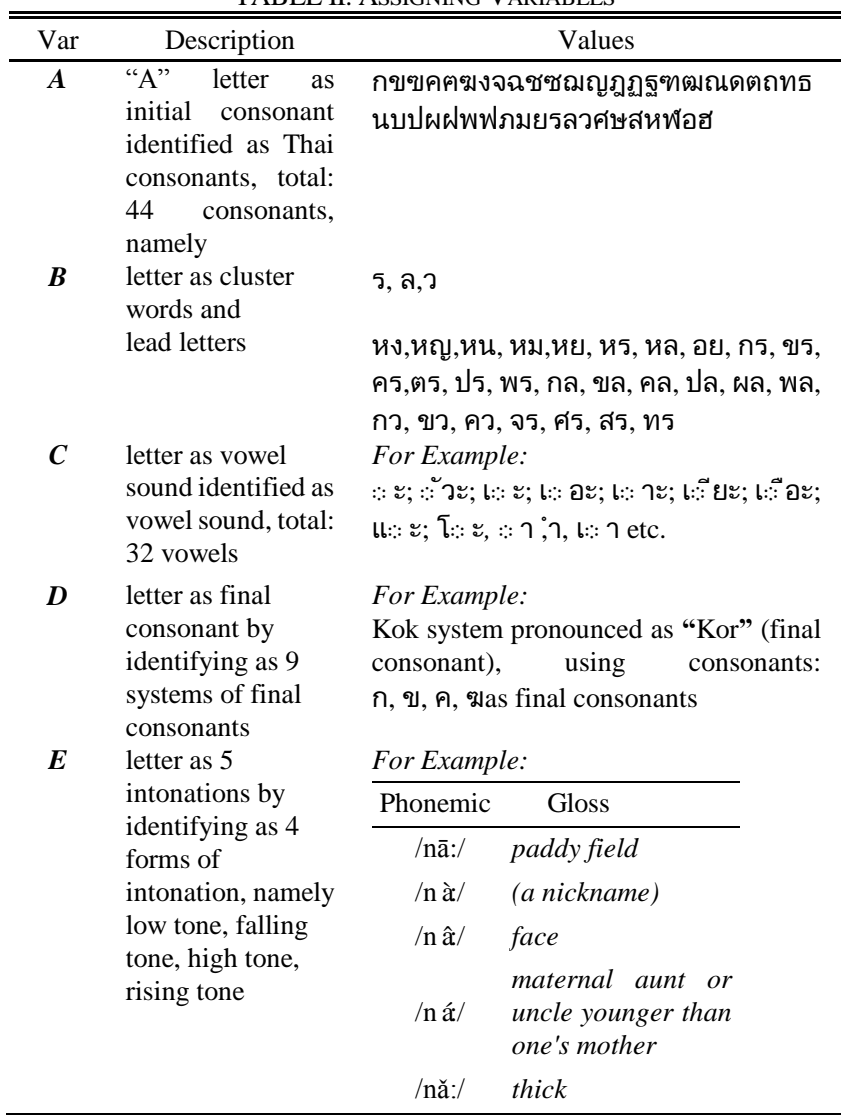

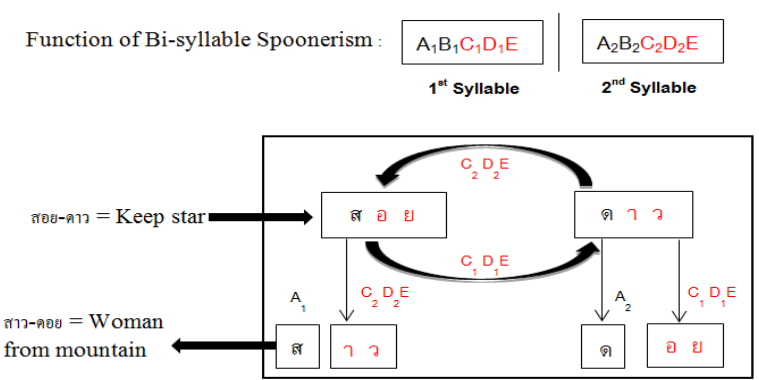

Fig. 5. Usage of rules of bi-syllable spoonerism.

\section{B. Conceptual in Bi-syllable Spoonerism}

Form the Fig. 5, the explanations are as follow: the formula usage of bi-syllable spoonerism uses cross-encryption, that is to say, the value of initial consonant (A) and cluster word (B) is preserved; only vowel, intonation mark and final consonant will be conducted cross-encryption. From the above examples, the word, such as สอย-ดาว"Søi-dao", when encrypting in Bi-syllable spoonerism, the answer will, for example, be สาว-ดอย“Sao-døi” [10].

\section{Conceptual Tri-syllable Spoonerism}

From the study, it is found that Tri-syllable Thai spoonerism has 2 cases of spoonerism mechanism from $\mathrm{Bi}$-syllable Concept. In the first case is a crossing between the second syllable to the third syllable (Fig. 6) and second case is a crossing between the first syllable to the third syllable (Fig. 7).

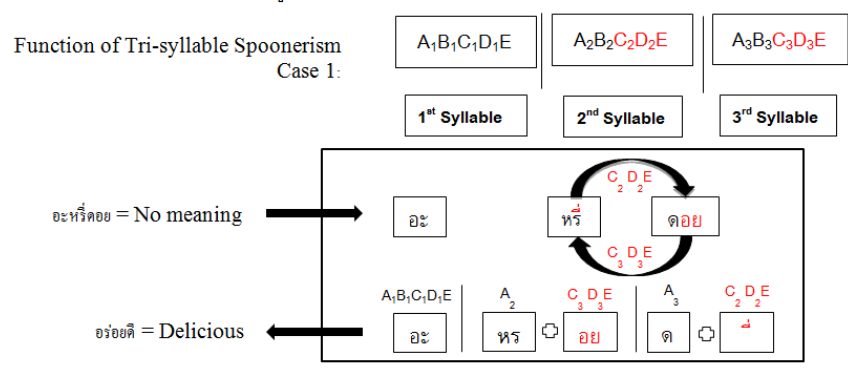

Fig. 6. Usage of rules of case 1 tri-syllable spoonerism.

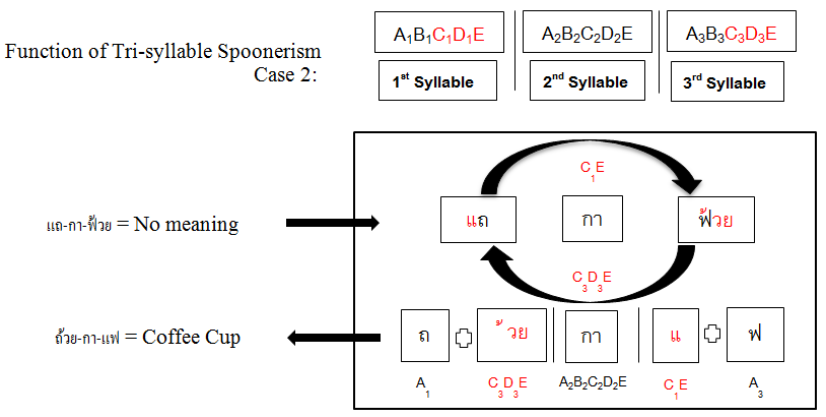

Fig. 7. Usage of rules of case 2 tri-syllable spoonerism.

\section{Function in Tri-syllable Spoonerism}

TABLE III: VARIABLES IN SPOONERISM FUNCTION

\begin{tabular}{ll}
\hline \hline \multicolumn{1}{c}{ Var } & \multicolumn{1}{c}{ Description } \\
\hline $\mathrm{Sp}$ & Obtained Spoonerism Word \\
$\mathrm{S}_{1}$ & First Syllable \\
$\mathrm{S}_{2}$ & Second Syllable \\
$\mathrm{ch}_{1}$ & First Letter \\
$\mathrm{ch}_{2}$ & Second Letter \\
$\mathrm{ch}_{3}$ & Third Letter \\
$\mathrm{ch}_{\mathrm{n}}$ & Other Letter of First Syllable \\
$\mathrm{ch} 2_{\mathrm{n}}$ & Other Letter of Second Syllable \\
$\mathrm{Cons}$. & Consonant \\
$\mathrm{Clus}$. & Cluster Words \\
Itone. & Intonation Marks \\
Vow. & Vowel \\
+ & Character Connector \\
$\mathrm{n}$ & Other Number of Character \\
\hline \hline
\end{tabular}

An analysis of elements of syllables are conducted 
according to letters in elements of each syllable, which can analyzed into 2 cases, that is, the first letter of each syllable can be both initial consonant and vowel. From the preliminary analysis of the syllable, probability could be used for searching the second letter of each syllable in order to conduct function analysis in spoonerism as Table III.

In case of Bi-syllable the first syllable and second syllable have the first letter as consonant, the second consonant as vowel, all of which could be analyzed according to probability and create functions in spoonerism as อา-กี "ākî" (no meaning in Thai language) to be อี-กา "īkā" (crow in Thai language) substituting the formula of spoonerism as follows:

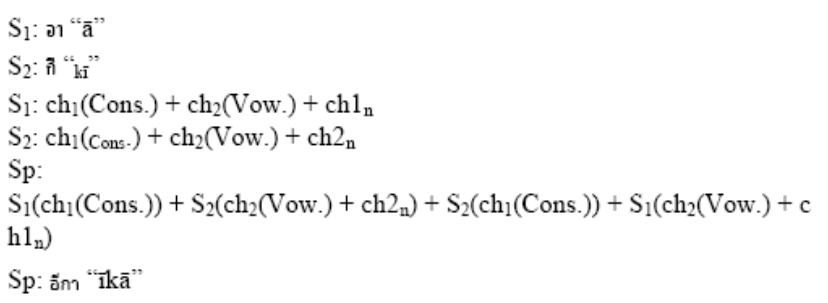

In case of Tri-syllable the each syllable have the first letter as consonant, the second consonant as vowel, all of which could be analyzed according to probability and create functions in spoonerism as แกก-ตก-แต้ว "kak-tok-taew" (no meaning in Thai language) to be แก้ว-ตก-แตก "kaew-tok-tak" (broken glass falls) substituting the formula of spoonerism as follows:

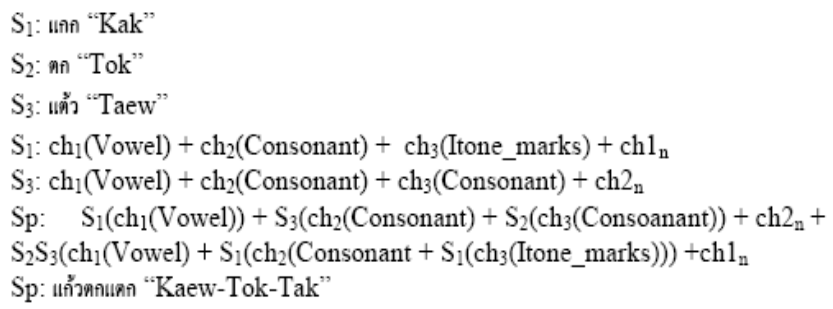

\section{E. Thai Spoonerism Algorithm in Computer Language}

For functions and algorithm in semi-automatic Thai spoonerism, the research has developed the program by PHP language utilizing algorithm structure in order to analyze the elements of syllables; moreover, the principle of probability was brought to establish rules and mechanisms in spoonerism which could specify conditions as follows:

Fig. 8 represents a specification of variables of Tri-syllable, namely variables of consonant, cluster word, vowel and intonation mark, then, input value from keyboard which used by users for entering words into blanks is received and kept in Array and a conditional variables of elements of syllable are created according to probability of the syllables. This algorithm of functions will keep the value of each syllable which users have entered in the form of one Array per letter for applying in rules of Tri-syllable spoonerism, further.

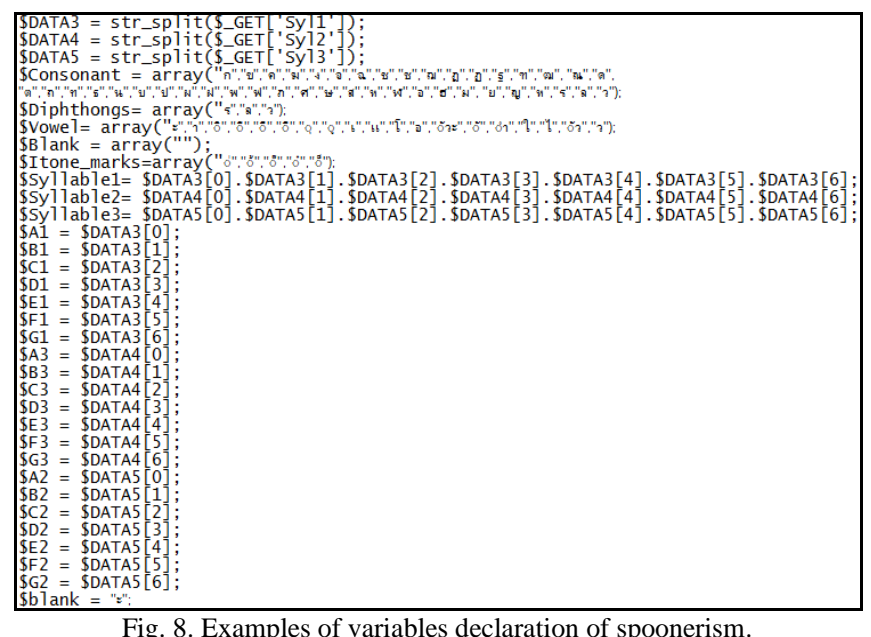

Fig. 8. Examples of variables declaration of spoonerism.

From Fig. 9, Code of instance in Tri-syllable spoonerism: first syllable, second syllable and third syllable, first letter is consonant, second letter is vowel, having algorithm and functions as the program will examine the value of letter at first field of each syllable that the value are in conformity with specified conditions, after that the program will examine the value of second letter of each syllable that the value are in conformity with specified conditions. If the conditions of examined letter is true the program will display the value for notifying users that the spoonerism word that was conducted spoonerism are in conformity with which case of the program and display the value of each syllable which was entered by users preliminary and the program will display spoonerism words that was conducted spoonerism according to the rules specified conditions in each case as each of such case is different in code for specifying different conditions.

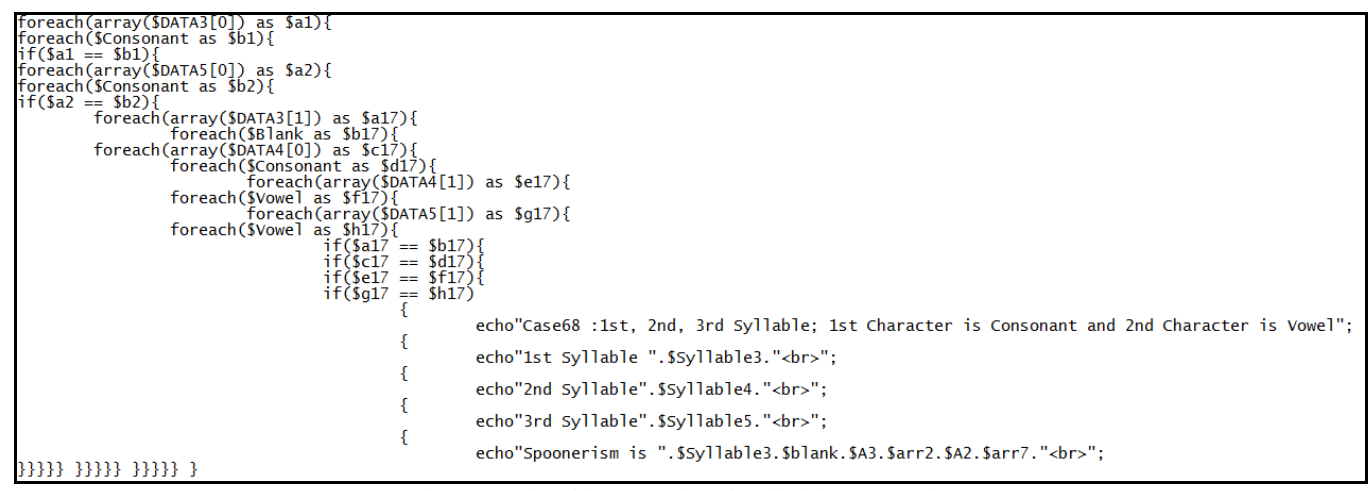

Fig. 9. Code of instance in tri-syllable spoonerism.

\section{CONCLUSION}

The test of Tri-syllable Thai spoonerism demonstrates that in Tri-syllable Thai spoonerism, initial consonant and cluster word (if any) are stable; however, vowel, intonation mark and final consonant of first syllable and second syllable will be 
transposed. From the above performance test (200 Records of Thai spoonerism dataset), it is found that syllable having cluster word (second letter is ร,ล and ว) could be enter words in 2 cases, but the result of spoonerism words is only one answer. Accuracy in Thai Tri-syllable could be analyzed at $90 \%$.

The development of semi-automatic Thai spoonerism has a working principle of program, that is, an examination of first letter, if the first letter is consonant, second letter will be examined. If the second letter is cluster word, the system will examine third letter of syllable whether such syllable is vowel, intonation mark and final consonant or not. If the third letter is vowel, intonation mark and final consonant, the program will transpose one of the elements of syllable to other syllable, then display an output at monitor. If the second letter is not cluster word (second letter is the elements, namely vowel, intonation mark and final consonant), the program will transpose the value of the elements at the position of second letter to be transposed with other syllable, then display an output at monitor. Correctness of spoonerism word could be examined by inverting word needed to conduct spoonerism in order to obtain the answers in spoonerism with effectiveness and select a correct answer for application, further.

\section{REFERENCES}

[1] E. A. Nida, Morphology, The University of Michigan Press, 1947

[2] P. F. Macneilage, Personal Communication, 1968.
[3] R. H. Robbins, "The warden's wordplay: Toward a redefinition of thespoonerism," Dalhousie Rev., vol. 46, pp. 457-465, 1966.

[4] D. G. Mackay, "Spoonerisms: The structure of errors in the serial order of speech," University of California, Los Angeles, California, 1969.

[5] W. Siriwatananawin, "Spoonerism: A creative way of communication in Thai," in Proc. the Asian Conference on Asian Studies, 2013, pp. 135-141.

[6] S. Pongpaibool, "Principal of Thai language," Thai Wattanapanich Press, Bangkok, 2001.

[7] R. M. S. Heffner, General Phonetics, University of Wisconsin Press, Madison, 1964.

[8] U. Warosickadith, Introduction to Thai Language, Ramkhamhaeng University Press, Bangkok Thailand, 2002.

[9] F. L. Wells, Linguistic Lapses, Science Press, New York, 1906

[10] N. Kaewrattanapat and W. Bunchongkien, "The algorithm of semi-automatic thai spoonerism words for bi-syllable," International Journal of Computer, Information, Systems and Control Engineering, vol. 8, no. 8, pp. 1318-1322, 2014.

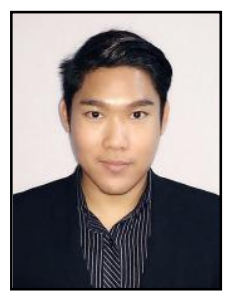

Nutthapat Kaewrattanapat was born on March 8 1983 in Thailand and received his B.S. degree with $1^{\text {si }}$ class honors in computer science and M.S. degree in management information system. $\mathrm{He}$ is a $\mathrm{Ph} . \mathrm{D}$. candidate in information technology from King Mongkut's University of Technology North Bangkok, Thailand. $\mathrm{He}$ is currently a faculty member of Information Management Program, Suan Sunandha Rajabhat University since 2009. His research focuses on information technology, computational linguistic, natural language processing and data mining. 